\title{
Stratigraphy of Maastrichtian Foraminiferida from the United Kingdom; the Maastrichtian of Norfolk
}

\author{
M. Hart ${ }^{1} \&$ T. Swiecicki ${ }^{2}$ \\ ${ }^{1}$ Department of Geological Sciences, University of Plymouth, Drake Circus, \\ PLYMOUTH PL4 8AA, United Kingdom; e-mail: M.Hart@plymouth.ac.uk \\ 2 Cerebus Consultants, 'Saroka', Bailbrook Lane, BATH BA1 7AA, United Kingdom
}

Manuscript received: June 2000; accepted: June 2001

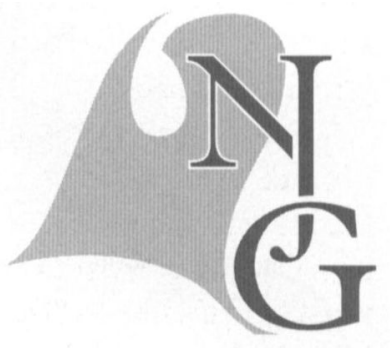

\begin{abstract}
Onshore Maastrichtian strata in the United Kingdom are limited to a few small, isolated blocks of chalk floating within glacial sediments on the Norfolk coast. Isolated outcrops of Campanian and Maastrichtian chalks used to be available around Norwich but the majority of these exposures are now badly degraded. Offshore, in the North Sea Basin, there are complete chalk successions that range throughout the Upper Cretaceous and Lower Cenozoic. There is a limited succession of Maastrichtian chalks exposed on the north coast of Northern Ireland below the Cenozoic flood basalts. In the Western Approaches Basin, Maastrichtian and Danian chalks are known from exploration wells and core samples. West of the United Kingdom a number of DSDP/ODP boreholes have penetrated the Upper Cretaceous succession.

Beginning in the Cenomanian, in southeast England, the whole of the Upper Cretaceous is within the chalk facies, possibly one of the longest intervals of relatively stable environment in the geological record. The Foraminiferida of the chalk have been studied for more than a hundred years and therefore the fauna is exceptionally well known and fully documented. Fifty years ago, the benthonic Foraminiferida were identified as having the potential to provide a viable zonation of the chalk facies and we now have precise, cross-basinal correlation using these taxa.

The planktonic fauna is restricted by both palaeolatitude and water depth. The latter appears to be the most influential as the faunas from onshore are more limited than those recorded from the deeper waters of the North Sea Basin and the Atlantic Margin. Even with this restricted fauna, however, it is still possible to develop a general correlation with the standard Tethyan zonation based on planktonic taxa.
\end{abstract}

Keywords: Foraminiferida, Norfolk, Maastrichtian, biostratigraphy

\section{Introduction}

The Maastrichtian strata of the United Kingdom may be grouped under five main areas (Fig. 1) for the purposes of micropalaeontological investigations:

- the onshore chalk succession of Norfolk;

- the onshore chalk succession of Northern Ireland;

- the offshore succession of the North Sea Basin;

- the offshore successions south and west of the United Kingdom, and

- the offshore successions of the Atlantic Margin (DSDP/ODP sites).
In the present account it is the onshore chalk succession of Norfolk that is the focus of attention. The chalks in Northern Ireland (Hancock, 1961; Wood, 1967), which are located below the Cenozoic basalts, are relatively hard and, as a result, difficult to process for Foraminiferida. There are, however, a few accounts of the fauna provided by Wright $(1875,1886)$ and McGugan (1957). Work begun by one of us $(\mathrm{MH})$ in 1967 was terminated as a result of the political unrest in the area at that time and has not been restarted. The chalks of the North Sea Basin have, on the contrary, been intensively studied as a result of 
hydrocarbon exploration, especially in the Central Graben where chalks of Maastrichtian and Paleocene age are economic targets. While Swiecicki (1980) and Ball (1985) have studied selected boreholes from the southern North Sea Basin that have been released for student projects, much of the data remains confidential, although King et al. (1989) have provided a valuable summary of the biostratigraphy. In other offshore areas there are few published data available as the Maastrichtian strata are not an economic target. Recently, Van den Akker et al. (2000) have described the Maastrichtian succession in the Faroes-Shetland Basin (Fig. 1). On the Atlantic Margin off southwest England, and the edge of the Bay of Biscay, a number of DSDP/ODP wells have been drilled and the foraminiferal micropalaeontology described by Sigal
(1985), Ball (1985), Hart \& Ball (1986), Hart \& Duane (1989) and Schönfeld \& Burnett (1991).

A full description of the Foraminiferida and biostratigraphy of all these areas is beyond the scope of this account and, as a result, only the Norfolk succession will be considered in any detail.

\section{The Maastrichtian chalk of Norfolk}

The Upper Campanian and Lower Maastrichtian chalks of Norfolk are exposed in scattered, small, largely abandoned quarries or pits, coastal cliffs and glacially transported masses or erratics (Fig. 2). The first major investigation of the succession was that of Rowe, although his observations are only recorded in the form of manuscripts and field notebooks that are

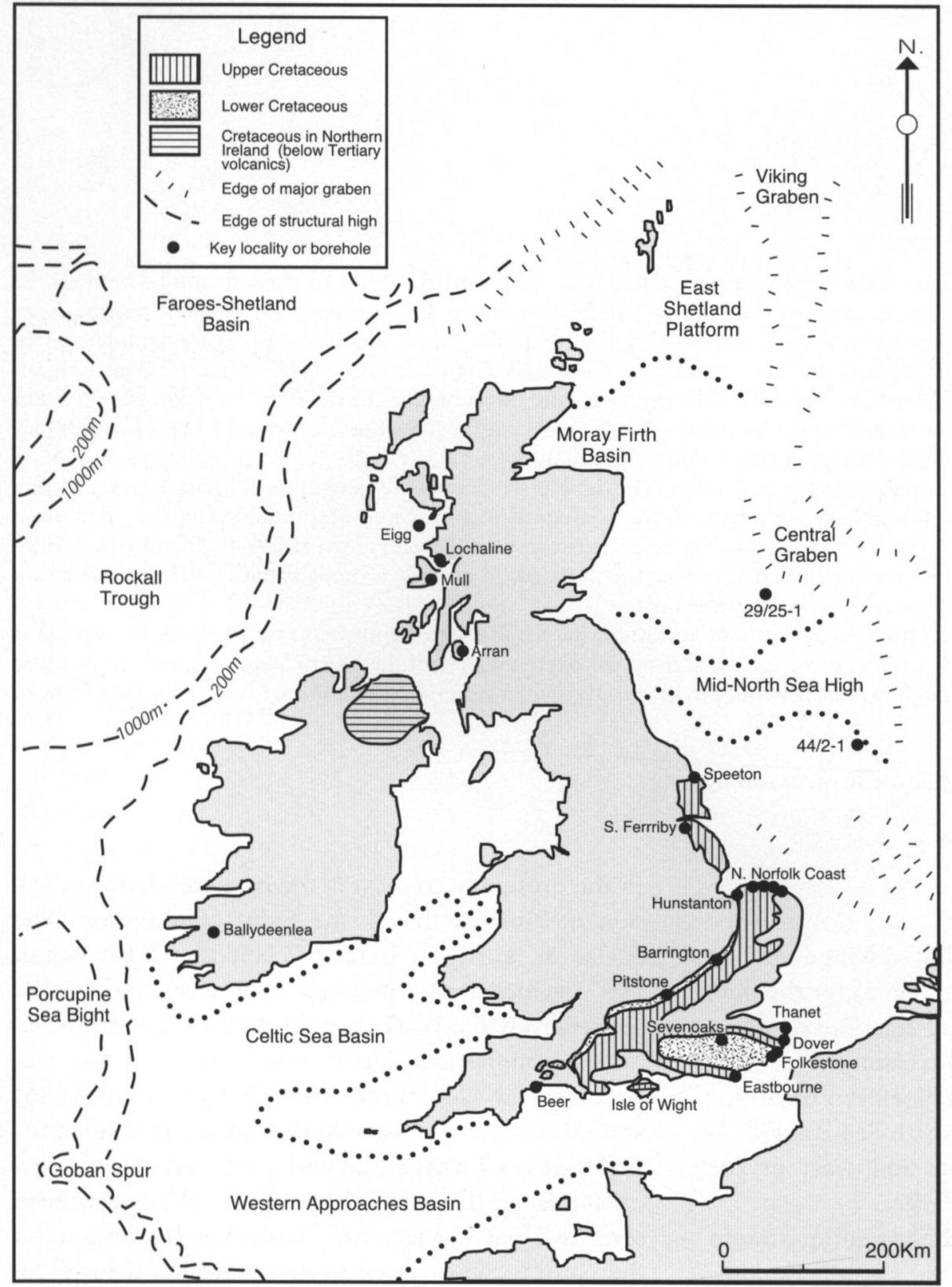

Fig. 1. The distribution of Cretaceous rocks in the United Kingdom with some of the key locations and boreholes identified. 


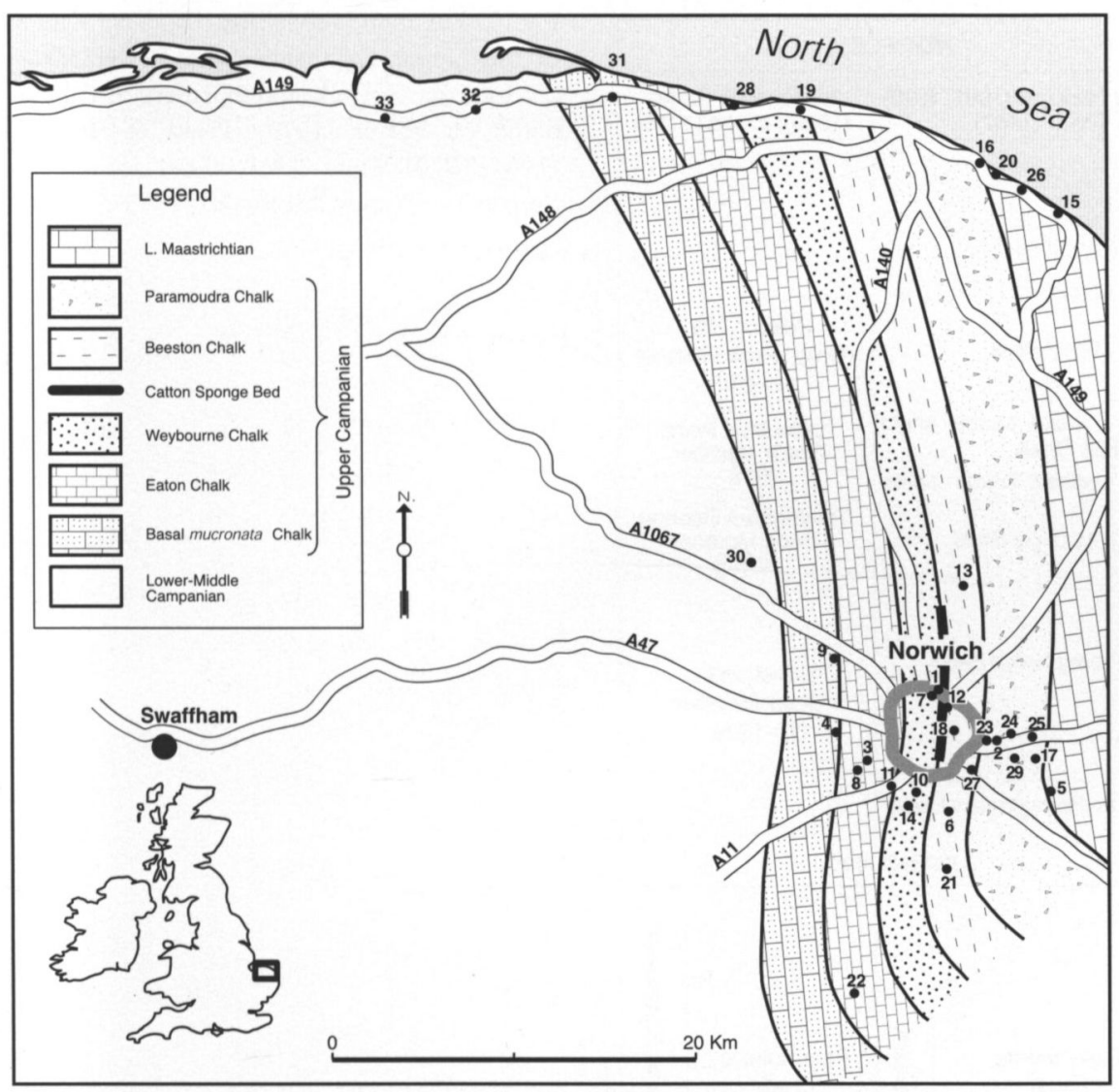

Fig. 2. Sketch map of the Campanian and Lower Maastrichtian localities and sections of Norfolk, based on data in Peake \& Hancock (1970), Swiecicki (1980), Johansen \& Surlyk (1990) and Christensen (1995). The localities identified on the map are as follows: 1. Attoe's pit; 2. Bishops Close; 3. Bluebell Road; 4. Bowthorpe Hall; 5. Bramerton; 6. Caistor St. Edmunds; 7. Catton Grove; 8. Cringleford; 9. Drayton; 10. Eaton Golf Course; 11. Eaton Limeworks; 12. Edward's pit, Mousehold; 13. Frettenham; 14. Keswick; 15. Little Marl Point; 16. Overstrand; 17. Postwick; 18. St. James; 19. Sherringham; 20. Sidestrand; 21. Stoke Holy Cross, Tharston; 23. Thorpe-next-Norwich; 24. Thorpe St. Andrew; 25. Thorpe Tollgate; 26. Trimingham; 27. Trowse; 28. Weybourne; 29. Whitlingham; 30. Alderford Common; 31. Cley; 32. Stiffkey Hall Farm; 33. Wells-next-the-Sea.

conserved in the Palaeontology Library of The Natural History Museum, London (see Wood, 1988 for details). Early in the twentieth century, Brydone (1906, $1908,1909,1930,1938)$ produced a series of reports and descriptions of the succession, eventually creating a number of 'units' that were later adapted by Peake \& Hancock (1970, pl. 2) into a geological map of the area. Brydone's 'units' were based on a combination of lithological characters and palaeontology; while using locality names they were essentially defined on palaeontological content. These were refined by Peake \& Hancock $(1961,1970)$ and further developed by Wood $(1967,1988)$. These 'units' are, therefore, neither true biozones or true lithostratigraphical subdivisions and were identified as faunal belts by Wood (1988). More recently, Johansen \& Surlyk (1990) have used the lithostratigraphical data from the North Sea Basin (e.g., Deegan \& Scull, 1977; Svendsen, 1979) to generate a more lithologically based nomenclature using members. Johansen \& Surlyk (1990) indicated that there are no major lithological variations in the chalk of the area and only concentrated on the identification of members. These are shown in Fig. 3 and while a hiatus is identified at the Campanian/Maastrichtian boundary it must be recognised that the interval represented by the gap is probably very slight. The presence of this hiatus is based on the observations of Christensen (1995, p.
12, text-fig. 3) which indicate that, '.... The earliest forms of Belemnella from Norfolk, however, are more advanced than the earliest forms from Kronsmoor (Schulz, 1978; Fletcher \& Wood, 1978)'. The potential/probable hiatus at the Campanian/Maastrichtian boundary will be discussed in terms of the foraminiferal biostratigraphy in a later section. The lithostratigraphy of the chalk in the whole of the United Kingdom is currently under review, although an initial report (Professor P.F. Rawson, pers. comm.) provided to one of us $(\mathrm{MH})$ appears to have omitted mention of the Maastrichtian chalks of Norfolk.

The chalk exposures, pits and quarries in Norfolk are now, reportedly, further degraded than when the material for this investigation was collected (1978/79). Many of the old pits around Norwich (Fig. 2) have been infilled and, in places, barely a few metres of chalk are visible. It is clear that some of our descriptions (Swiecicki, 1980) indicate a reduction in the size of the exposure since the work of Peake \& Hancock (1961, 1970). The Maastrichtian chalks are, generally, restricted to the coastal section between Overstrand (No. 16) and Little Marl Point (No. 15) on the Norfolk coast (Fig. 2). In this stretch of coastline many isolated masses of chalk may be seen, some of which reach a considerable size. Many of these masses may be seen to be completely enclosed within the till, whilst others are exposed only on the fore- 


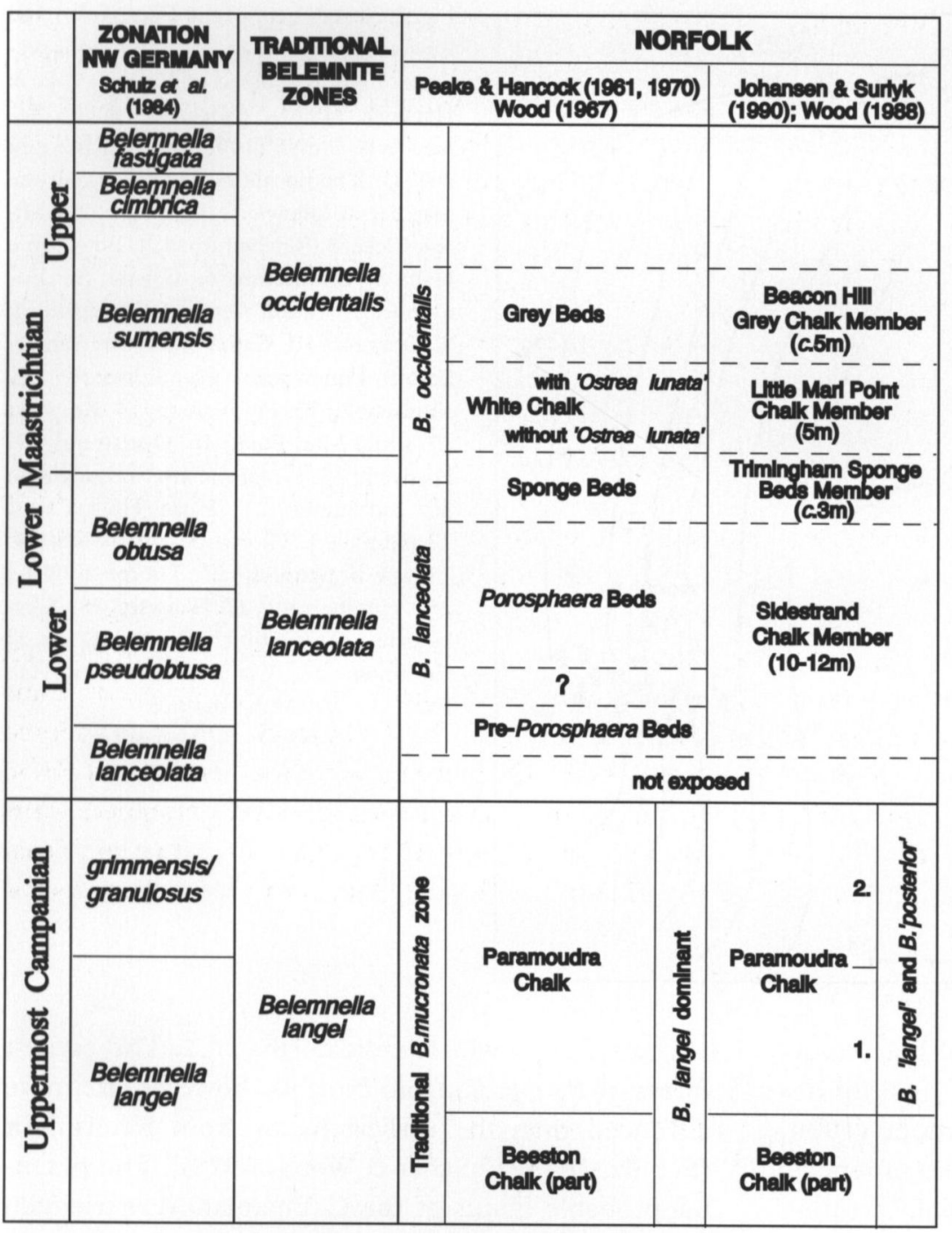

Fig. 3. Zonation, subdivisions and correlation of the Upper Campanian and Lower Maastrichtian in Norfolk and northern Germany, based on Schulz (1979), Peake \& Hancock (1961, 1970), Wood (1967, 1988), Johansen \& Surlyk (1990) and Christensen (1995).

shore, and their relationship to the Pleistocene deposits is not readily discernible. In many cases the structure and internal stratigraphy of these masses are complex and difficult to determine, given the vagaries of exposure at any one time. However, over a hundred years of careful observation of the constantly changing patterns of exposure (Lyell, 1840; Trimmer, 1847; Reid, 1882; Bonney \& Hill, 1905; Brydone, 1906, 1908, 1909, 1938; Peake \& Hancock, 1961，1970; Wood, 1967,1988 ) have produced a relatively clear understanding of the overall geometry and structure of most of the masses.

Many of these masses are completely enclosed within the till. There is also a complete gradation in scale from blocks little more than $1.0 \mathrm{~m}$ in size, showing clear evidence of having been transported within the till, to those over $300 \mathrm{~m}$ in length. These features, readily discernible in the field, provide overwhelming support for an origin as glacial erratics for all these diverse masses (Peake \& Hancock, 1961, 1970). Many of the larger masses (e.g., Sidestrand) show complex overfolding with shallow dipping northern limbs and vertical to overturned southern limbs, whilst others show one erratic piled on top of others. The latter mode is clearly exemplified by the Runton Mass, where most of the successive erratic 'slices' are capped by Crag and are clearly delineated from one another. The Overstrand Hotel Lower Mass also shows frequent overthrusting, though this is not a readily discernible as that of the Runton erratics, being marked by a series of relatively thin marl bands containing Pleistocene gravel. The method of erosion of the chalk, and subsequent incorporation within the till, has been a subject of considerable debate (Reid, 1882; Peake \& Hancock, 1961, 1970). It is now thought (N.B. Peake, pers. comm.) that salt doming, possibly initiated as a result of increased loading due to the development of extensive Pleistocene ice sheets, raised the surface of the chalk in a number of places to a level where some of it could be eroded by surges within the ice sheet. Transport and deformation of the soft chalk as part of the bed load of a southerly-moving ice sheet, and eventual deposition on the flanks of the positive Cromer Ridge, produced 
the outcrop pattern which we see today. Similar features have been recognised over a wide area of NW Europe, including NW Germany and Denmark, notably at Møns Klint (Håkansson et al., 1974). The fact that all the Norfolk chalk erratics investigated lie almost directly above in situ chalk of a comparable stratigraphic horizon, strongly indicates that glacial transportation took place almost exactly along the line of strike of the chalk. This is suggestive of a possible source area in the direction of the Leman Bank, where diapiric structures are recorded (N.B. Peake \& J.M. Hancock, pers. comm.).

Overstrand Hotel Lower Mass (grid reference; TG 255 406)

This is by far the largest chalk mass to outcrop in the Overstrand area. In form, it is a roughly tabular body, some $100 \mathrm{~m}$ in length and $13 \mathrm{~m}$ high, occupying the cliff beneath the site of the former Overstrand Hotel. The centre of the mass is essentially horizontal, whilst at either end it is slightly uptilted giving it an overall concave aspect. The extreme western end of the mass exhibits a relatively accessible section of chalk some $13 \mathrm{~m}$ in height and with an apparent dip of $16.5^{\circ}$ to the south. Close examination of this face reveals the presence of at least three marly layers containing quartz pebbles derived from the till. These have been interpreted as thrust planes (see Fig. 4). The maximum recorded thickness of any one thrust slice is $\mathbf{5 . 2}$ $\mathrm{m}$. The base of the mass was excavated and found to clearly rest on glacial clay. Flint bands are developed throughout the section. The uppermost thrust slice contains occasional paramoudra flints. Samples were collected at regular intervals throughout the section, in order to determine whether the sequence represented a repetition of a single horizon or an accumulation of stratigraphically distinct levels.

The stratigraphic position of the mass has been a matter of some considerable debate, which has not been aided by the general scarcity of macrofauna within the mass. Peake \& Hancock (1961) considered the mass to be of latest Campanian age, whilst Wood (1967) stated that the mass possibly contained layers of both uppermost Campanian and Lower Maastrichtian chalk. Peake \& Hancock (1970) later specu-

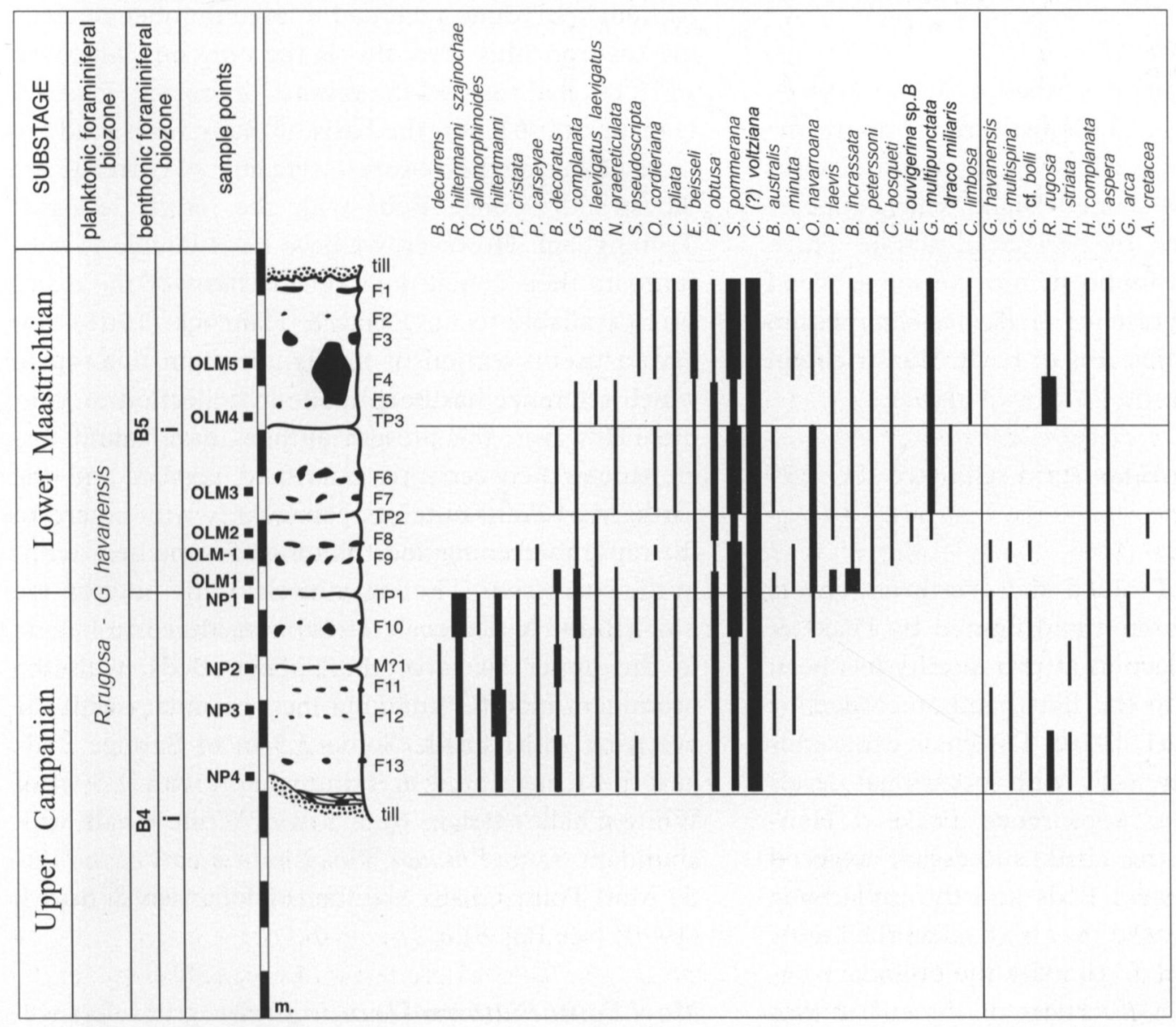

Fig. 4. Distribution of Foraminiferida in the Overstrand Hotel Lower Mass (after Swiecicki, 1980). The full details of the taxa are given in Appendix 1. The thrust planes are indicated as TP1, TP2 and TP3. Note: This is a selection of the taxa present in the succession and represents what are perceived to be the stratigraphically most useful species. 
lated that the entire mass might be of Early Maastrichtian age, with the Campanian/Maastrichtian boundary being placed at the level of the underlying, indurated Pyramidata Reef. Johansen \& Surlyk (1990) appear to follow this suggestion, although as far as the authors are aware, no examples of the characteristic Early Maastrichtian belemnite, Belemnella lanceolata (von Schlottheim, 1813), have ever been recorded from this section. The foraminiferal evidence presented in the present account indicates that the lowermost thrust slice may represent the uppermost Campanian while the remaining three slices are of Early Maastrichtian age; a position that supports the evidence of Wood (1967).

\section{Overstrand Minor Mass}

This small erratic was observed by one of us (TS) within the till west of the above mass. It consisted of a mass of white, soft chalk, approximately $1.0 \mathrm{~m}$ across, with an extensive drawn out 'tail'. No macrofauna was present within the mass.

Overstrand Hotel Upper Mass (grid reference: TG 255 406)

This mass was originally described by Wood (1967). It crops out within the till almost directly above the Overstrand Hotel Lower Mass. This section exposes some $3.3 \mathrm{~m}$ of yellow-stained chalk, which appears to have been shattered by periglacial action. Three flint bands have been found within the mass. Wood (1967) recorded the presence of $B$. lanceolata within the mass, confirming that it is of Early Maastrichtian age.

Sidestrand Western Mass (grid reference: TG 255 404)

This complex series of folded and overthrust erratic blocks have been described and figured by Peake $\&$ Hancock (1961). Collection at this locality has been made with reference to the flint bands recorded by Peake \& Hancock $(1961,1970)$. The chalk exposed is white and moderately soft, with occasional levels showing a grey mottled appearance. Peake \& Hancock (1961) divided the chalk succession exposed here into the Porosphaera Beds and the underlying Pre-Porosphaera Beds, and they have taken the highly distinctive flint horizon ' $S$ ' to mark the boundary between the two units. A thickness of some $4 \mathrm{~m}$ was measured for the Pre-Porosphaera Beds and approximately the same for the Porosphaera Beds.
Sidestrand Sponge Bed Platform (grid reference: TG 255 404)

The sponge beds were only exposed on the foreshore during this investigation as a result of a fortuitous combination of tides and winds. The succession was described in detail by Peake \& Hancock (1961), and the sample collection has been made with respect to their recorded sequence of beds. A total thickness of $2.8 \mathrm{~m}$ was measured, extending from flint bands ' $\mathrm{P}$ ' to ' $\mathrm{K}$ '. Lithologically, the sponge beds represent a complex of erosion surfaces with marl bands and glauconite coated chalk nodules; a typical hardground complex (Kennedy \& Garrison, 1975). The chalk here is grey, with levels relatively rich in glauconite and pyrite and is indurated. Wood (1967) recorded the first appearance of Belemnella 'occidentalis' within the sponge beds and tentatively placed the base of the eponymous zone at this level. Sponges, belemnites and echinoids are abundant at this level.

TriminghamlLittle Marl Point (grid reference: TG 298 380)

Although Brydone recorded a large number of chalk masses from this area, this is the only one which, in $1978 / 79$, had resisted the ravages of erosion. Peake \& Hancock (1961), on the basis of many years study of these changeable exposures, were able to correlate the Sidestrand Sponge Beds with the lowest levels at Trimingham. However, we have been unable to substantiate their conclusions on the basis of the exposures available to us. Peake \& Hancock (1961) also gave a useful section of the Trimingham outcrop to which reference has been made in collection of samples. However, the present authors have found discrepancies between this published section and the Little Marl Point outcrop, particularly with regard to the rapid thickening and thinning of some beds within the succession. The lower levels of the outcrop are now (Peake \& Hancock, 1970) considered to belong to the upper levels of the Sponge Beds, with the prominent marl ' $G$ ' marking their boundary with the overlying white chalk. Some $2.5 \mathrm{~m}$ of Sponge Beds have been measured at Trimingham, with $1.5 \mathrm{~m}$ of White Chalk overlain by $2.5 \mathrm{~m}$ of White Chalk with abundant 'Ostrea'lunata. This is now a part of the Little Marl Point Chalk Member of Johansen \& Surlyk (1990) (see Fig. 3).

Marl Point Platform/Trimingham (grid reference: TG 294 384)

This chalk platform may still be exposed at certain 
times of year. The chalk seen on the platform is grey, but also contains ' $O$.' lunata and, therefore, cannot be assigned to the Grey Beds sensu stricto (Peake \& Hancock, 1970).

In order to complete the Maastrichtian succession in this region, Swiecicki (1980) and Hart et al. (1989) used two suites of samples from North Sea exploration wells 44/2-1 and 29/25-1 which were kindly provided by Shell Exploration \& Production Ltd. and Esso Exploration \& Production. The locations of these two wells are shown in Fig. 1.

\section{Foraminiferal analysis}

Samples averaging $0.5 \mathrm{~kg}$ in weight were collected from all onshore sections studied at a stratigraphical interval of approximately $1.0 \mathrm{~m}$ and from as narrow a stratigraphical interval as was practical (about 10 $\mathrm{cm}$ ). An interval of $1.0 \mathrm{~m}$ was selected as the optimum spacing to maximise stratigraphic resolution, whilst minimising the effects of bioturbation (Bromley et al., 1975) and sedimentation problems (Berger \& Heath, 1968). Spot samples were also taken from horizons of distinct lithological change (e.g., above omission surfaces), from marly chalks and from 'flint meal'. Samples from the offshore boreholes were supplied as cuttings from $30 \mathrm{ft}(9.14 \mathrm{~m})$ intervals from well $29 / 25-1$ and at $10 \mathrm{ft}(3.05 \mathrm{~m})$ intervals from well 44/2-1.

Samples with a slight clay content were processed using the white spirit (solvent) technique, which is described in Brasier (1980). The resulting sediment was washed over a $75 \mu \mathrm{m}$ sieve which, although large by today's standards, was normal at the time of the investigation. For chalks that were pure carbonate, or too hard for the above method, the samples were subjected to very gentle crushing under water. Once broken down they were also washed on the $75 \mu \mathrm{m}$ sieve. Although this sounds a harsh method for sample preparation it is effective, and when tests were run on the bias it introduces in the resulting residues, it was found to be as reliable as other (e.g., hydrogen peroxide) methods. In all cases the samples were inspected in the following size fractions: $>500 \mu \mathrm{m}, 500-250 \mu \mathrm{m}$, 250-125 $\mu \mathrm{m}$ and 125-75 $\mu \mathrm{m}$.

Whilst detailed foraminiferal data is available for all the successions outlined above (Swiecicki, 1980), for the purposes of this summary only a detailed analysis of the Sidestrand Hotel Lower Mass (Fig. 4) is provided. The overall succession of the chalk in Norfolk is shown in Fig. 5. In both cases the taxa listed are a selection of the total fauna.

In the succession of chalk shown in Fig. 4, the three thrusts are indicated as TP1, TP2 and TP3. These are extended across the ranges of the species in order to identify the various thrust slices. The species listed are a selection of the stratigraphically most useful taxa, as a full faunal list would include $80+$ species and subspecies. It is noticeable that there are faunal changes across the thrusts. This either indicates that there are slight/significant gaps in the stratigraphic record or implies differing preservation in the four slices. The faunal succession is, however, quite comparable to some other areas (NW Germany, see Schönfeld, 1990; Goban Spur, see Schönfeld \& Burnett, 1991) and so the blocks of chalk are regarded as being:

- in the correct stratigraphic order; and

- unlikely to be separated by major breaks in the succession.

The whole succession belongs in the Rugogloberigerina rugosa/Globotruncanella havanensis planktonic foraminiferal biozone (Swiecicki, 1980) or the Globotruncanella havanensis Interval Zone (UKP.15) of Hart et al. (1989). There are, unfortunately, no particularly diagnostic planktonic species recorded from this succession. The only feature of note is the 'flood' of $R$. rugosa at the base of the upper thrust slice. This may be significant in terms of the water depth at the locality, and may reflect a flooding event, in terms of sequence stratigraphical nomenclature. Throughout the Campanian/Maastrichtian succession (Fig. 5), there is a largely 'boreal' feel to the planktonic fauna with none of the 'Tethyan' markers (see Fig. 6) being recorded. In the DSDP/ODP boreholes to the southwest of the United Kingdom, Ball (1985), Hart \& Ball (1986) and Hart \& Duane (1989) recorded an increased number of Tethyan taxa (including, amongst others, Globotruncanita calcarata, Gansserina gansseri, Globotruncana aegyptiaca, $G$. ventricosa) and attributed this to the difference in water depths in the two areas. Johansen \& Surlyk (1990) also commented on the shallow-water depths represented by the Norfolk chalks as compared to those in the North Sea Basin. If one attempts to correlate (Fig. 6) the distribution of planktonic species in Norfolk with that of the standard zonation (reproduced from Robaszynski \& Caron, 1995) it is clear that only the Abathomphalus mayaroensis Zone appears to be reliable (using the deeper water successions of the North Sea Basin; borehole 44/2-1). While Contusotruncana contusa is also known from the North Sea Basin it is uncertain as to whether the first appearance is the absolute time equivalent of that in the standard Tethyan zonation. All the other taxa used in Tethyan environments ( $G$. calcarata, G. gansseri, G. aegyptiaca, and others) are absent from Norfolk and the North Sea Basin and 


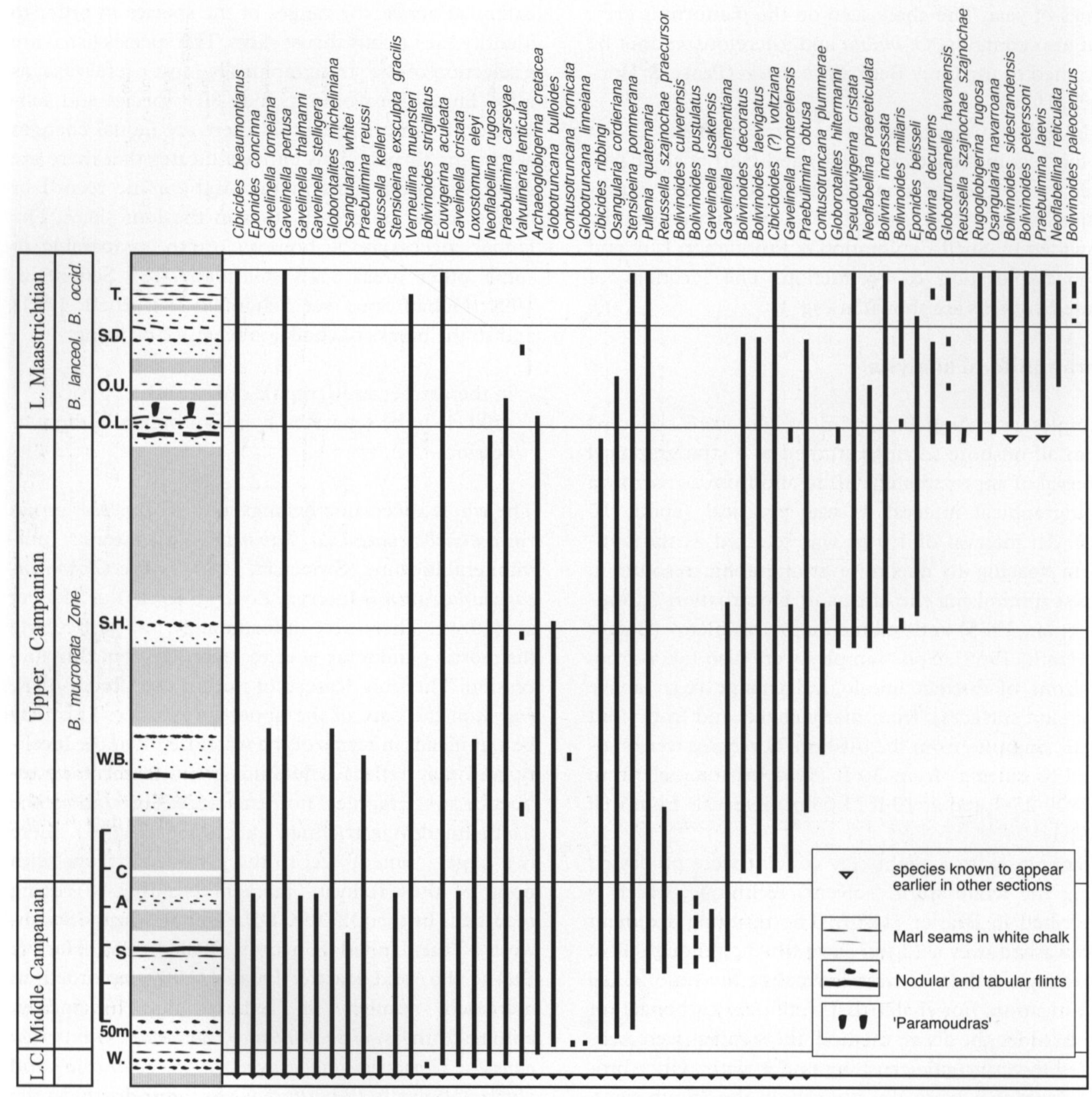

Fig. 5. The uppermost Lower Campanian to Lower Maastrichtian succession of Norfolk, which is a composite based on data in Swiecicki (1980) and Hart et al. (1989). The full details of the taxa are given in Appendix 1. Note: This is a selection of the taxa present in the succession and represents what are perceived to be the stratigraphically most useful species. The successions used in the construction of this diagram are as follows: Wells-next-the-Sea (W); Stiffkey Hall Farm (S); Alderford Common (A); Cley (C); Weybourne (WB); Sherringham (SH); Overstrand Hotel Lower Mass (OL; see Fig. 4); Overstrand Hotel Upper Mass (OU); Sidestrand (SD); Trimingham (T).

while there are taxa common to both areas (G. ventri$\cos a$ and Globotruncanella havanensis) it is almost impossible to use them for precise correlation (Fig. 6).

The distribution of the smaller benthonic species is more valuable for correlation within the white chalk facies of NW Europe. Using this fauna it is possible to generate a viable zonation (see Hart et al., 1989) for correlation across western Russia, Poland, northern Germany (Koch, 1977; Schönfeld, 1990), Scandinavia, northern France, United Kingdom, the
Netherlands, Belgium and the North Sea Basin (King et al., 1989). This zonation is primarily based on the progressively evolving lineages of taxa in the (relatively) stable environment of the Late Cretaceous chalk seas. The principal taxa used in the zonation include species of Bolivinoides (Swiecicki, 1980), Gavelinella (Edwards, 1981; Hart \& Swiecicki, 1988) and Stensioeina (Koch, 1977). In the Sidestrand Hotel Lower Mass succession (Fig. 4), the lowest thrust slice is attributed to biozone B4 (the Bolivinoides draco miliaris 


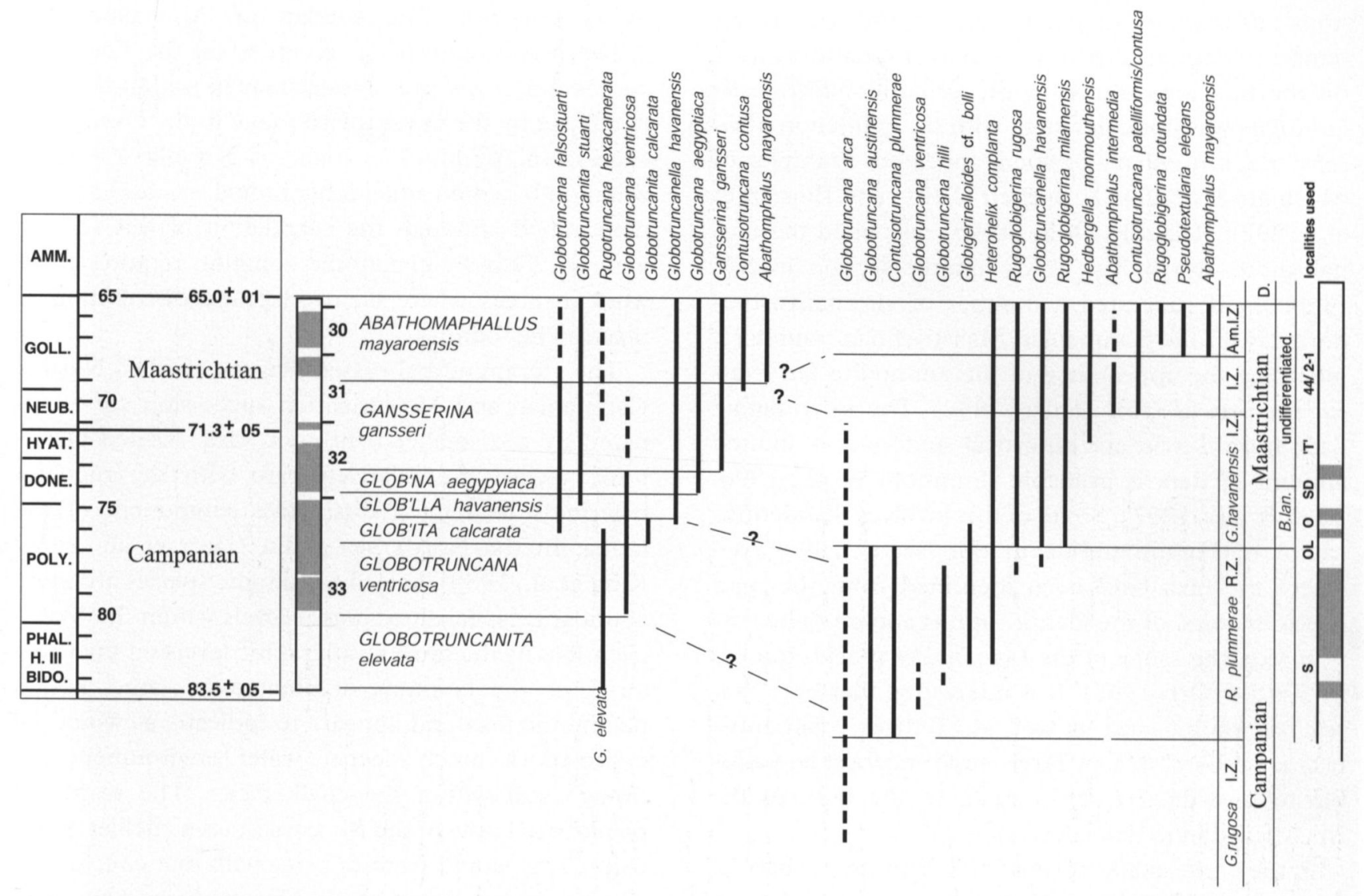

Fig. 6. Tentative correlation of the Norfolk and North Sea Basin successions with that of the standard Tethyan planktonic foraminiferal, zonation of Robaszynski \& Caron (1995). The localities used are Sherringham (S), Overstrand Hotel Lower Mass (OL), Overstrand Hotel Ụpper Mass (O), Sidestrand (S) and Trimingham (T), together with the North Sea borehole 44/2-1. The interval zones listed above the Globotrincanella havanensis Interval Zone are the Contusotruncana contusa Interval Zone (I.Z.) and the Abathomphalus mayaroensis Interval Zone.

Partial Phylozone of Swiecicki, 1980) which equates to the Bolivinoides miliaris Interval Zone (UKB.19) of Hart et al. (1989). The overlying thrust slices are attributed to biozone $\mathrm{B} 5$ (the Bolivinoides peterssoni Partial Phylozone of Swiecicki, 1980) which is equated with the Bolivinoides peterssoni Interval Zone (UKB.20) of Hart et al. (1989).

The lowest thrust slice does have a quite distinctive fauna with Globorotalites hiltermanni, Bolivina decurrens and Reussella s. szajnochae. The flood of R. s. szajnochae is used as a marker across the North Sea Basin (King et al., 1989) and has recently been identified in an identical stratigraphical position in the FaroesShetland Basin by Van den Akker et al. (2000, fig. 3). The upper three thrust slices present a more consistent fauna with the appearance of Bolivinoides peterssoni, Bolivina incrassata and Praebulimina laevis. The overlying chalk masses at Overstrand, Sidestrand and Trimingham present an almost uniform fauna with the only key change being the appearance of the Bolivinoides paleocenicus Interval Zone within the Sidestrand succession (see Fig. 5). Using offshore material, Swiecicki (1980) and Hart et al. (1989) identified another zone in the Upper Maastrichtian, based on the appearance of Bolivinoides $d$. draco. The distinctive Neoflabellina lineage (N. rugosa, N. praereticulata, $N$. reticulata), although stratigraphically useful, is not used in our zonation scheme.

\section{The Campanian/Maastrichtian boundary}

In the works of Swiecicki (1980) and Hart et al. (1989), the base of the B. peterssoni Interval Zone was used as the Campanian/Maastrichtian boundary (see Fig. 5) with the coincident extinction of $G$. hilterman$n i$ and Gavelinella monterelensis being used as supplementary evidence. The flood of $R$. s. szajnochae was also used as a distinctive biomarker. These reports were, however, produced before the international debate generated by the publication of the planktonic foraminiferal zonation of Robaszynski et al. (1984) which suggested that the Campanian/Maastrichtian boundary could be drawn at the extinction of Globotruncanita calcarata. This suggestion was a response to the pragmatic approach of many oil companies, who regularly use extinction events (so-called 
'tops') as markers for stratigraphic boundaries. In attempts to demonstrate that the boreal zonation, based on the first appearance of the belemnite Belemnella lanceolata was not coincident with the extinction of $G$. calcarata, a number of papers appeared, examples of which are Schönfeld \& Burnett (1991) and Burnett et al. (1992). Recently, Odin (1996) described the faunal succession of the Tercis quarry section in SW France and suggested a number of alternative biohorizons for the Campanian/Maastrichtian boundary, including the appearance of the ammonite Pachydiscus neubergicus (von Hauer, 1858). The microfaunal data from Tercis are equivocal and only a limited amount of data is available (Simmons et al., 1996; Ward \& Orr, 1997). Some of this involves the identification of Foraminiferida in thin section, but even where the taxa have been identified from the marl horizons some of the identifications appear to be suspect (e.g. the range of the Bolivinoides species quoted by Ward \& Orr, 1997). It is interesting that both 'boreal' benthonic taxa as well as 'Tethyan' planktonic taxa are recorded from Tercis and it may yet be possible to provide a reliable guide to the base of the Maastrichtian in that succession.

In the white chalk facies of NW Europe the base of the Belemnella lanceolata Zone in the Lägerdorf quarry (Schönfeld, 1990, fig. 2) is drawn within the upper part of the $B$. peterssoni/G. hiltermanni Concurrent Range Zone. This zone is not recognised in Norfolk where the two species do not have overlapping ranges. In the Overstrand Hotel Lower Mass (Fig. 4), these taxa are recorded either side of the lowermost thrust plane (TP.1). The other taxa that have ranges terminating or beginning around this interval have been highlighted by Schönfeld \& Burnett (1991, fig. 4). This would imply that, in the Overstrand Hotel Lower Mass, we might be missing a very small amount of time (= strata) at the key boundary (= approximately $6 \mathrm{~m}$ of strata in the Lägerdorf section using Schönfeld's (1990, fig. 8) log). The small gap in the Norfolk record is that interval suggested in Fig. 3 and (probably) that identified by Christensen (1995). There are, however, other taxa in this critical interval (e.g., $G$. monterelensis, Bolivinoides decoratus, B. laevigatus, Bolivina decurrens, $P$. laevis and $R$. s. szajnochae) which may provide better resolution of the boundary issue.

\section{Summary}

The white chalk succession of Norfolk is described in terms of the foraminiferal biostratigraphy. As far as can be ascertained, the 'local' base of the Maastrichtian is present in the Overstrand Hotel Lower Mass and can be identified by the appearance of Bolivi- noides peterssoni. The overlap of this taxon with Globorotalites hiltermanni, recorded in the Lägerdorf succession, is not present and may lie within the strata cut out by the lower thrust plane in the Overstrand succession. Within the chalk of Norfolk a reliable zonation based on smaller benthonic species has been determined although the correlation of this scheme with the Tethyan planktonic zonation requires more work in areas where an overlapping distribution of taxa can be found.

The foraminiferal assemblages of the Norfolk Campanian and Maastrichtian succession are dominated by the smaller benthonic taxa. Keeled planktonic species are relatively rare with the rugoglobigerinids forming a distinctive component of the fauna. In the North Sea Basin (Hart et al., 1989; King et al., 1989), keeled planktonic species are more abundant, especially at higher levels within the Maastrichtian. At the same stratigraphic levels on the Goban Spur the fauna is dominated by large, keeled planktonic taxa and appears to indicate, as would be expected, a much deeper water environment, although still within the chalk facies. The restricted planktonic fauna of the Maastricht area (Bellier \& Villain, 1975) would seem to agree with that conclusion. The benthonic fauna of the Maastrichtian type area, which contains larger benthonic taxa (amongst others, Siderolites, Omphalocyclus, Orbitoides) that may have contained algal symbionts, also indicates deposition in a relatively shallow-water environment. The chalks of Norfolk are, therefore, an intermediate environment between those of the Maastricht area and the chalks deposited in the deeper-water environments of the North Sea Basin and the Goban Spur.

\section{Acknowledgements}

The authors wish to thank N.B. Peake, Professor J.M. Hancock, C.J. Wood, Dr H. Ernst, Dr J. Schönfeld, Professor F. Surlyk, Dr W.K. Christensen and many others for help in the field and constructive advice on the stratigraphy of the Campanian and Maastrichtian stages in the UK. TS was supported by an NERC research studentship (1976-1979), while $\mathrm{MH}$ has been supported by numerous grants from the University of Plymouth, the Royal Society and NERC. J. Abraham is thanked for his careful preparation of the final figures.

\section{Appendix}

Species identified in the diagrams and the text are listed below (in alphabetical order) with their full name: 
Abathomphalus intermedius (Bolli, 1951)

Abathomphalus mayaroensis (Bolli, 1951)

Archaeoglobigerina cretacea (d'Orbigny, 1840)

Bolivina decurrens (Ehrenberg, 1854)

Bolivina incrassata Reuss, 1851

Bolivinoides australis Edgell, 1954

Bolivinoides culverensis Barr, 1967

Bolivinoides decoratus (Jones, 1875)

Bolivinoides draco draco (Marsson, 1878)

Bolivinoides draco miliaris Hiltermann \& Koch, 1950

Bolivinoides laevigatus Marie, 1941

Bolivinoides paleocenicus (Brotzen, 1948)

Bolivinoides peterssoni Brotzen, 1945

Bolivinoides pustulatus Reiss, 1954

Bolivinoides sidestrandensis Barr, 1966

Bolivinoides strigillatus (Chapman, 1892)

Cibicides beaumontianus (d'Orbigny, 1840)

Cibicides ribbingi Brotzen, 1936

Cibicidoides? voltziana (d'Orbigny, 1840)

Contusotruncana contusa (Cushman, 1926)

Contusotruncana fornicata (Plummer, 1931)

Contusotruncana patelliformis (Gandolfi, 1955)

Contusotruncana plummerae (Gandolfi, 1955)

Coryphostoma limbosa (Cushman, 1931)

Coryphostoma pliata (Carsey, 1926)

Eouvigerina aculeata (Ehrenberg, 1854)

Eponides beisseli Schijfsma, 1946

Eponides concinna Brotzen, 1936

Gansserina gansseri (Bolli, 1951)

Gavelinella clementiana (d'Orbigny, 1840)

Gavelinella complanata (Reuss, 1851)

Gavelinella cristata (Goel, 1965)

Gavelinella lorneiana (d'Orbigny, 1840)

Gavelinella monterelensis (Marie, 1941)

Gavelinella multipuncta (Bandy, 1951)

Gavelinella pertusa (Marsson, 1878)

Gavelinella stelligera (Marie, 1941)

Gavelinella thalmanni (Brotzen, 1936)

Gavelinella usakensis (Vasilenko, 1961)

Globigerinelloides aspera (Ehrenberg, 1854)

Globigerinelloides bolli Pessagno, 1967

Globorotalites hiltermanni Kaever, 1961

Globorotalites micheliniana (d'Orbigny, 1840)

Globotruncana aegyptiaca Nakkady, 1950

Globotruncana arca (Cushman, 1926)

Globotruncana austinensis Gandolfi, 1955

Globotruncana bulloides Vogler, 1941

Globotruncana falsostuarti Sigal, 1952

Globotruncana hilli Pessagno, 1967

Globotruncana ventricosa White, 1928

Globotruncanella havanensis (Voorwijk, 1937)

Globotruncanita calcarata (Cushman, 1927)

Globotruncanita elevata (Brotzen, 1934)

Globotruncanita stuarti (de Lapparent, 1918)
Hedbergella monmouthensis (Olsson, 1960)

Heterohelix complanata (Marie, 1941)

Loxostomum eleyi (Cushman, 1927)

Neoflabellina praereticulata Hiltermann, 1952

Neoflabellina reticulata (Reuss, 1851)

Neoflabellina rugosa (d'Orbigny, 1840)

Osangularia cordieriana (d'Orbigny, 1840)

Osangularia navarroana (Cushman, 1938)

Osangularia whitei (Brotzen, 1936)

Praebulimina carseyae (Plummer, 1931)

Praebulimina laevis (Beissel, 1891)

Praebulimina obtusa (d'Orbigny, 1840)

Praebulimina reussi (Morrow, 1934)

Pseudotextularia elegans (Rzehak, 1891)

Pseudouvigerina cristata (Marsson, 1878)

Pullenia quaternaria (Reuss, 1851)

Pyramidina minuta (Marsson, 1878)

Quadrimorphina allomorphinoides (Reuss, 1860)

Reussella kelleri Vasilenko, 1961

Reussella szajnochae praecursor de Klasz \& Knipscheer, 1954

Reussella s. szajnochae (Grzybowski, 1896)

Rugoglobigerina milamensis Smith \& Pessagno, 1973

Rugoglobigerina rotundata Brönnimann, 1952

Rugoglobigerina rugosa (Plummer, 1927)

Rugotruncana hexacamerata (Brönnimann, 1952)

Stensioeina exsculpta gracilis Brotzen, 1945

Stensioeina pommerana Brotzen, 1936

Stilostomella pseudoscripta (Cushman, 1937)

Valvulineria lenticula (Reuss, 1845)

Verneuilina muensteri Reuss, 1854 


\section{References}

Ball, K.C., 1985. A foraminiferal biostratigraphy of the Upper Cretaceous of the southern North Sea Basin (UK sector). Plymouth Polytechnic (Plymouth) (unpubl. $\mathrm{PhD}$ thesis).

Bellier, J.-P. \& Villain, J.-M., 1975. Globotruncanidae de la série type du Maastrichtien (Limbourg méridional). Cahiers de Micropaléontologie 2: 3-14.

Berger, W.H. \& Heath, G.R., 1968. Vertical mixing in pelagic sediments. Journal of marine Research 26: 134-143.

Bonney, T.G. \& Hill, E., 1905. The Chalk Bluffs at Trimingham. Geological Magazine 42: 397-403, 524, 525.

Brasier, M.D., 1980. Microfossils. George Allen \& Unwin (London): $193 \mathrm{pp}$.

Bromley, R.G., Schulz, M.-G. \& Peake, N.B., 1975. Paramoudras: giant flints, long burrows and the early diagenesis of chalks. Biologiske Skrifter fra Dansk Videnskabernes Selskab 20: 1-31.

Brydone, R.M., 1906. Further notes on the stratigraphy and fauna of the Trimingham Chalk. Geological Magazine 43: 13-22, 7278, 124-131, 289-300.

Brydone, R.M., 1908. On the subdivisions of the Chalk of Trimingham (Norfolk). Quarterly Journal of the geological Society of London 64: 401-412.

Brydone, R.M., 1909. The Trimingham Chalk/South Bluff. Geological Magazine 46: 189, 190.

Brydone, R.M., 1930. The 'Norwich Chalk'. Transactions of the Norfolk and Norwich Natural History Society 13: 47-49.

Brydone, R.M., 1938. On correlation of some of the Norfolk exposures of Chalk with Belemnitella mucronata. Dulau \& Co. (London): $15 \mathrm{pp}$.

Burnett, J.A., Hancock, J.M., Kennedy, W.J. \& Lord, A.R., 1992. Macrofossil, planktonic foraminiferal and nannofossil zonation at the Campanian/Maastrichtian boundary. Newsletters on Stratigraphy 27: 157-172.

Christensen, W.K., 1995. Belemnitella from the Upper Campanian and Lower Maastrichtian of Norfolk, England. Special Papers in Palaeontology 51: $84 \mathrm{pp}$.

Deegan, C.E. \& Scull, B.J. (comp.), 1977. A standard lithostratigraphic nomenclature for the Central and Northern North Sea. Report of the Institute of Geological Sciences 77/25: 1-36.

Edwards, P.G., 1981. The foraminiferal genus Gavelinella in the Senonian of north-west Europe. Palaeontology 24: 391-416.

Fletcher, T.P. \& Wood, C.J., 1978. Cretaceous rocks. In: Wilson, H.E. \& Manning, P.I. (Eds): Geology of the Causeway Coast, Memoir for one-inch Geological Sheet 7(2): 84-1 15.

Håkansson, E., Bromley, R.G. \& Perch-Nielsen, K., 1974. Maastrichtian of north-west Europe: a pelagic shelf sediment. In: Hsü, K. \& Jenkins, H.C. (Eds): International Association of Sedimentologists, Special Publication 1:211-233.

Hancock, J.M., 1961. The Cretaceous System in Northern Ireland. Quarterly Journal of the geological Society of London 117: 1136.

Hart, M.B., Bailey, H.W., Crittenden, S., Fletcher, B.N., Price, R.J. \& Swiecicki, A., 1989. Cretaceous. In: Jenkins, D.G. \& Murray, J.W. (Eds): Stratigraphical atlas of fossil Foraminifera. British Micropalaeontological Society, Special Publication. Ellis Horwood Ltd. (Chichester): 273-371.

Hart, M.B. \& Ball, K.C., 1986. Late Cretaceous anoxic events, sea level changes and the evolution of the planktonic foraminifera. In: Summerhayes, C.P. \& Shackleton, N.J. (Eds): North Atlantic palaeoceanography. Geological Society Special Publication 21: 67-78.

Hart, M.B. \& Duane, A.M., 1989. Late Cretaceous development of the Atlantic Continental Margin off south-west England. Pro- ceedings of the Ussher Society 7: 165-167.

Hart, M.B. \& Swiecicki, A., 1988. The Genus Gavelinella Brotzen, 1942, in the Cretaceous strata of the UK. Revue de Paléobiologie, Vol. spéc. 2: 289-294.

Johansen, M.B. \& Surlyk, F., 1990. Brachiopods and the stratigraphy of the upper Campanian and Lower Maastrichtian Chalk of Norfolk, England. Palaeontology 33: 823-872.

Kennedy, W.J. \& Garrison, R.E., 1975. Morphology and genesis of nodular chalks and hardgrounds in the Upper Cretaceous of southern England. Sedimentology 22: 31 1-386.

King, C., Bailey, H.W., Burton, C.A. \& King, A.D., 1989. Cretaceous of the North Sea. In: Jenkins, D.G. \& Murray, J.W. (Eds): Stratigraphical atlas of fossil Foraminifera. British Micropalaeontological Society, Special Publication. Ellis Horwood Ltd. (Chichester): 372-417.

Koch, W., 1977. Biostratigraphie in der Oberkreide und Taxonomie von Foraminiferen. Geologisches Jahrbuch A38: 11-123.

Lyell, C., 1840. On the Boulder Formation, or drift and associated freshwater deposits composing the mud cliffs of Eastern Norfolk. Philosophical Magazine 3: 345-380.

McGugan, A., 1957. Upper Cretaceous Foraminifera from Northern Ireland. Journal of Paleontology 31: 329-348.

Odin, G.S. (comp.), 1996. Definition of a Global Boundary Stratotype Section and Point for the Campanian/Maastrichtian boundary. Bulletin de l'Institut royal des Sciences naturelles de Belgique, Sciences de la Terre 66 (Suppl.): 111-117.

Peake, N.B. \& Hancock, J.M., 1961. The Upper Cretaceous of Norfolk. Transactions of the Norfolk and Norwich Natural History Society 19: 293-339.

Peake, N.B. \& Hancock, J.M., 1970. The Upper Cretaceous of Norfolk. In: Larwood, G.P. \& Funnell, B.M. (Eds): The Geology of Norfolk. Transactions of the Norfolk and Norwich Natural History Society 19: 293-339 [269-375, reprinted with supplement].

Reid, C., 1882. The geology of the country around Cromer. Memoir of the Geological Survey of the United Kingdom.

Robaszynski, F. \& Caron, M., 1995. Foraminifères planctoniques du Crétacé: commentaire de la zonation Europe-Méditerranée. Bulletin de la Société géologique de France 166: 681-692.

Robaszynski, F., Caron, M., Gonzalez Donoso, J.M. \& Wonders, A.A.H., 1984. Atlas of Late Cretaceous globotruncanids. Revue de Micropaléontologie 26: 145-305.

Schönfeld, J., 1990. Foraminiferen aus der Schreibkreide. Geologisches Jahrbuch A1 17: 1-151

Schönfeld, J. \& Burnett, J., 1991. Biostratigraphical correlation of the Campanian-Maastrichtian boundary: Lägerdorf-Hemmoor (northwestern Germany), DSDP Sites 548A, 549 and 551 (eastern North Atlantic) with palaeobiogeographical and palaeoceanographical implications. Geological Magazine 128: 479503.

Schulz, M.-G., 1978. Zur Litho- und Biostratigraphie des Obercampan/Untermaastricht von Lägerdorf und Kronsmoor (SW/ Holstein). Newsletters on Stratigraphy 7: 73-89.

Schulz, M.-G., 1979. Morphometrisch-variationsstatische Untersuchungen zur Phylogenie der Belemniten-Gattung Belemnella im Untermaastricht NW-Europas. Geologisches Jahrbuch A47: 3-157.

Sigal, J., 1985. Foraminifers. Cretaceous. In: Site 551, Initial Reports of the Deep Sea Drilling Program 80:357-385.

Simmons, M.D., Williams, C.L. \& Hancock, J.M., 1996. Planktonic foraminifera across the Campanian/Maastrichtian boundary at Tercis, south-west France. Newsletters on Stratigraphy 34: 6580.

Svendsen, N., 1979. The Tertiary/Cretaceous chalk in the Dan Field of the Danish North Sea. In: Christensen, W.K. \& 
Birkelund, T. (Eds): Symposium on Cretaceous/Tertiary boundary events. University of Copenhagen (Copenhagen): 112-119.

Swiecicki, A., 1980. A foraminiferal biostratigraphy of the Campanian and Maastrichtian chalks of the United Kingdom. Plymouth Polytechnic (Plymouth): $358+155$ pp. (unpubl. PhD thesis).

Trimmer, J., 1847. On the geology of Norfolk as illustrating the laws of the distribution of soils. Journal of the royal Agricultural Society London 7: 444-485.

Van den Akker, T.J.H.A., Kaminski, M.A., Gradstein, F.M. \& Wood, J., 2000. Campanian to Palaeocene biostratigraphy and palaeoenvironments in the Foula Sub-basin, west of the Shetland Islands, UK. Journal of Micropalaeontology 19:23-43.

Ward, P. \& Orr, W., 1997. Campanian-Maastrichtian ammonite and planktonic foraminiferal biostratigraphy from Tercis, France; implications for defining the stage boundary. Journal of Paleontology 71: 407-418.

Wood, C.J., 1967. Some new observations on the Maastrichtian Stage in the British Isles. Bulletin of the geological Survey of Great Britain 27: 271-288.

Wood, C.J., 1988. The stratigraphy of the chalk of Norfolk. Bulletin of the geological Society of Norfolk 38: 3-120.

Wright, J., 1875. A list of the Cretaceous microzoa of the north of Ireland. Proceedings of the Belfast Naturalists' Field Club, n.s. 1 (1873-1880), Appendix 3: 73-99.

Wright, J., 1886. A list of the Cretaceous Foraminifera of Keady Hill, County Derry. Proceedings of the Belfast Naturalists' Field Club (2)2: 327-332. 